\title{
OLFACTORY DETECTION OF CACHES CONTAINING WILDLAND VERSUS CULTIVATED SEEDS BY GRANIVOROUS RODENTS
}

\author{
Jennifer L. Hollander ${ }^{1,3,4}$, Stephen B. Vander Wall1,3, and William S. Longland2,3
}

\begin{abstract}
We conducted a study to examine the ability of granivorous rodents to detect caches made with wildland (native and nonnative) and cultivated seeds at 3 locations in western Nevada with different vegetation types and rodent community structures. We established artificial caches containing either 2 or 3 species of wildland seeds or cultivated seeds. Five seed species were tested at each site. Under dry conditions, rodents found caches containing cultivated seeds much more rapidly than caches containing wildland seeds. Wet conditions resulted in a similar order of detectability; however, all species of seeds were located much faster in wet conditions than under dry conditions. Natural selection has likely acted on the wildland seeds to reduce their olfactory signal and potentially reduce predation upon those seeds.

RESUMEN.-Llevamos a cabo un estudio para examinar la capacidad que poseen los roedores para detectar escondites de semillas forestales (nativas y no nativas) y de semillas de cultivos en tres localidades en el oeste de Nevada, con diferentes tipos de vegetación y diferentes comunidades de roedores. Establecimos escondites artificiales que contenían ya sea dos o tres especies de semillas forestales o semillas de cultivos. Se probaron cinco especies de semillas en cada sitio. En condiciones secas, los roedores encontraron más rápidamente los escondites que contenían semillas de cultivados que aquellos escondites que contenían semillas forestales. Las condiciones húmedas resultaron en un orden de detección similar. Sin embargo, todas las especies de semillas se localizaron más rápidamente en condiciones húmedas que en condiciones secas. Posiblemente, la selección natural haya actuado sobre las semillas forestales para reducir sus señales olfativas y reducir potencialmente la depredación de estas semillas.
\end{abstract}

Many species of rodents, birds, and insects subsist on a diet of seeds. These animals have a long evolutionary history of handling and consuming seeds (Tiffney 1984, Vander Wall 2001) and are thought to have acted as strong agents of natural selection on the size, structure, and composition of seeds and surrounding tissue (i.e., fruit). Seeds and fruits have evolved to increase the effectiveness of seed dispersal and to promote successful seedling establishment while reducing the likelihood of seed predation (Hulme and Benkman 2002).

One characteristic of seeds that has an important impact on seed predation, but has received less attention than other impacts, is the odor that they emit. Seed odor is especially relevant to rodents that forage for dispersed seeds on the soil surface or pilfer seeds scatter-hoarded by other animals (Johnson and Jorgensen 1981, Vander Wall and Jenkins 2003). Rodents that store seeds in soil use a combination of spatial memory and olfactory cues to retrieve those seeds (Jacobs and Liman 1991, Vander Wall 1991, Jacobs 1992). It is now well established that the odor emanating from seeds increases as seed or soil moisture increases (Vander Wall 1993, 1998) and that the ability of rodents to smell seeds varies with the weather (Vander Wall 2000). Some species of seeds have a stronger odor than others, which may make them more detectable by rodents (Jorgensen 2001).

There is probably strong selection on seeds to remain undetected by animals. Even if seeds are adapted for dispersal by scatterhoarding animals, once cached in soil, the seed's best interest is to not be found. Seeds that produce strong odors are more likely to be found and consumed, whereas seeds with weak odors are more likely to be overlooked. Consequently, seeds dispersed by scatter-hoarding animals might evolve relatively weak odors compared to other types of seeds.

The objective of this study was to compare the abilities of rodents to detect buried seeds of a variety of wildland and cultivated plants. We hypothesized that seeds of wildland plants that are dispersed primarily or exclusively by

${ }^{1}$ Department of Biology, University of Nevada, Reno, NV 89557.

${ }^{2}$ USDA, Agricultural Research Service, 920 Valley Road, Reno, NV 89512.

${ }^{3}$ The Program in Ecology, Evolution and Conservation Biology, University of Nevada, Reno, NV 89557.

${ }^{4}$ E-mail: jhollander@unr.edu 
TABLE 1. Species of seeds used at each study site, the type of seed, and the number of seeds in each cache. The number of seeds per cache was adjusted so that the mass of seeds per cache was similar across all seed species at that site.

\begin{tabular}{|c|c|c|}
\hline Site/seed species & Seed type & Seeds per cache \\
\hline \multicolumn{3}{|l|}{ Little Valley } \\
\hline Jeffrey pine & native, wildland & 2 \\
\hline Antelope bitterbrush & native, wildland & 16 \\
\hline Acorn squash & cultivated & 2 \\
\hline White millet & cultivated & $\sim 30$ \\
\hline Striped sunflower & cultivated & 2 \\
\hline \multicolumn{3}{|l|}{ Hot Springs Mountains } \\
\hline Indian ricegrass & native, wildland & 66 (SE 3) \\
\hline Desert needlegrass & native, wildland & $132(\mathrm{SE} 4)$ \\
\hline Cheatgrass & introduced, wildland & $110(\mathrm{SE} 4)$ \\
\hline White millet & cultivated & $41(\mathrm{SE} 1)$ \\
\hline Black-oil sunflower & cultivated & 6 \\
\hline \multicolumn{3}{|l|}{ Red Rock } \\
\hline Antelope bitterbrush & native, wildland & 11 \\
\hline Mormon tea & native, wildland & 17 \\
\hline Cheatgrass & introduced, wildland & $110(\mathrm{SE} 4)$ \\
\hline White millet & cultivated & 41 (SE 1) \\
\hline Black-oil sunflower & cultivated & 6 \\
\hline
\end{tabular}

rodents should be under strong selection to minimize odors when those seeds are buried in dry soil. Alternatively, commercial seeds that have been bred for their nutritional value or oil content are probably not under selection for minimizing odors. The different selective environments experienced by wildland and cultivated seeds should affect the strength of odors that those seeds emit, and we should be able to detect those differences by measuring rates of cache removal by rodents.

\section{Methods}

We tested the abilities of rodents to detect buried seeds in 3 habitats. The first was a Jeffrey pine-antelope bitterbrush association in the Whittell Forest on the east slope of the Carson Range, approximately $30 \mathrm{~km}$ south of Reno, Washoe County, Nevada. Yellow-pine chipmunks (Tamias amoenus), long-eared chipmunks (Tamias quadrimaculatus), and deer mice (Peromyscus maniculatus) are the most common species of scatter-hoarding rodents in this habitat. Here we had 3 study sites within about $1 \mathrm{~km}$ of each other. We tested 5 seed species: Jeffrey pine (Pinus jeffreyi), antelope bitterbrush (Purshia tridentata), black oil sunflower (Helianthus annuus), white millet (Panicum miliaceum), and acorn squash (Curcurbita реро; Table 1). The pine and bitterbrush seeds are native seeds that are cached extensively by chipmunks and deer mice and are among the most important dietary items of rodents at this site (Kuhn and Vander Wall 2008, 2009). The sunflower and millet are commercially available seeds with a long history of artificial selection. We used squash seeds because they were large, readily available, and probably not under strong selection for odors that they emit.

Second, the Hot Springs Mountains, approximately $70 \mathrm{~km}$ east of Reno, is a Great Basin Desert site dominated by salt-tolerant shrubs such as fourwing saltbush (Atriplex canescens), Bailey's greasewood (Sarcobatus baileyi), and indigo bush (Psorothamnus polydenius). Merriam's kangaroo rats (Dipodomys merriami), desert kangaroo rats (Dipodomys deserti), pale kangaroo mice (Microdipodops pallidus), and little pocket mice (Perognathus longimembris) are the most common rodents. Here we tested Indian ricegrass (Achnatherum hymenoides), desert needlegrass (Achnatherum speciosum), sunflower, millet, and cheatgrass (Bromus tectorum). Indian ricegrass, the most common native grass at this site, is cached and dispersed by rodents (Longland et al. 2001). Desert needlegrass is a native grass that is far less abundant at the site than its congener, Indian ricegrass, but it can be found emerging as seedlings from rodent caches where it does occur. Cheatgrass is an introduced annual grass that is locally abundant and highly invasive. Although it only became apparent in the Hot Springs Mountains in 1994, it is frequently cached by rodents occurring at the site, and emergence of aggregated seedlings from rodent caches has been common in most years since 
its establishment. Sunflower and millet are preferred commercial seeds commonly used as bait to capture granivorous rodents.

Red Rock, approximately $10 \mathrm{~km}$ north of Reno, is another Great Basin Desert site where sagebrush (Artemisia tridentata), desert peach (Prunus andersonii), antelope bitterbrush, and green ephedra (Ephedra viridis) are the dominant woody shrubs, and cheatgrass composes most of the herbaceous understory. Panamint kangaroo rats (Dipodomys panamintinus) and Great Basin pocket mice (Perognathus parvus) are the most abundant rodents. Here we tested antelope bitterbrush, green ephedra, cheatgrass, white millet, and black oil sunflower seeds. The bitterbrush and ephedra seeds are native seeds gathered, cached, and dispersed by rodents at this site. Cheatgrass was introduced to the type of sagebrush environment that this site typifies $>100$ years ago and has been common in such environments for $>50$ years (Mack 1981).

All seeds used for trials were fresh and had intact hulls. We preconditioned seeds by placing them in mesh bags and burying the bags in the soil at each site. The bags were left in the soil for one week before being used for this study. We wore gloves any time we handled the seeds and used spoons and forceps to make the caches. This was all done to eliminate human odors as much as possible.

At each site, we established transects consisting of stations about $5 \mathrm{~m}$ apart. At each station we buried seeds of one plant species about $10 \mathrm{~mm}$ deep, with the number of seeds in each cache adjusted such that the mass of seeds was similar (Table 1). We marked caches inconspicuously with natural objects (cones, twigs, pebbles, etc.) in unique combinations, but otherwise disguised cache sites, leaving no visible indications of our digging. The order of the 5 seed species in caches along transects at each site changed in a regular sequence such that caches with seeds of the same species were approximately $25 \mathrm{~m}$ apart. In Little Valley (pine forest habitat), transects consisted of 300 stations with 60 caches of each species of seed, replicated at the 3 sites. At Red Rock and Hot Springs Mountains (desert scrub habitat), transects consisted of 200 stations with 40 caches of each species of seed, replicated twice at each site. We established transects when the soil was dry. We then monitored caches daily for the first 3 days and then at intervals of 2-5 days until most caches had been found or it rained. Any time the soil was disturbed at a cache site, we verified that the seeds were gone before considering the cache "found." At the pine forest site, we initiated trials on 5 August 2003 and again on 1 September 2004. We also initiated a third series of trials just after it rained (wet soil) on 17 October 2003. At the desert sites, we initiated trials on 25 October 2005, 15 May 2006, and 23 June 2008 at the Hot Springs Mountains and on 30 September 2004, 28 September 2005, and 14 May 2008 at Red Rock.

We analyzed the differences in the rate of removal among the 5 seed species at each location using survival analysis (Proc Lifereg in SAS 2000, SAS Institute, Inc., Cary, NC) with interval censoring and a Weibull distribution (Allison 1995). We analyzed each site separately because we used different seed species at each site. Because removal events were not observed, we used 2 response variables to bracket the time of seed removal: last present (the last time we saw seeds present at their station-lower limit of survival time) and first absent (the first time we recorded seeds as absent-upper limit of survival time). Following Allison (1995), we censored data for seeds that were either removed before our first check or were still present at the end of the study, and we used chi-square statistics to compare relative rates of removal among the 5 seed species at each site.

\section{RESUlTS}

At Little Valley, cultivated seeds disappeared from caches more quickly than wildland seeds during dry conditions, with sunflower disappearing more quickly than any other seed type (Fig. 1A). Sunflower seeds disappeared 5.2 times faster than Jeffrey pine $\left(\chi^{2}=66.46, P<\right.$ $0.0001), 4.8$ times faster than bitterbrush $\left(\chi^{2}\right.$ $=62.26, P<0.0001)$, 3.7 times faster than acorn squash $\left(\chi^{2}=45.47, P<0.0001\right)$, and 2.6 times faster than millet seeds $\left(\chi^{2}=26.67\right.$, $P<0.0001)$. Millet seeds were removed 2.0 times faster than Jeffrey pine $\left(\chi^{2}=11.11, P=\right.$ $0.0009)$ and 1.8 times faster than bitterbrush $\left(\chi^{2}=8.86, P=0.0029\right)$. There were no other significant differences in removal rates among different seed types.

As expected, all seed species were removed significantly faster under wet conditions than 

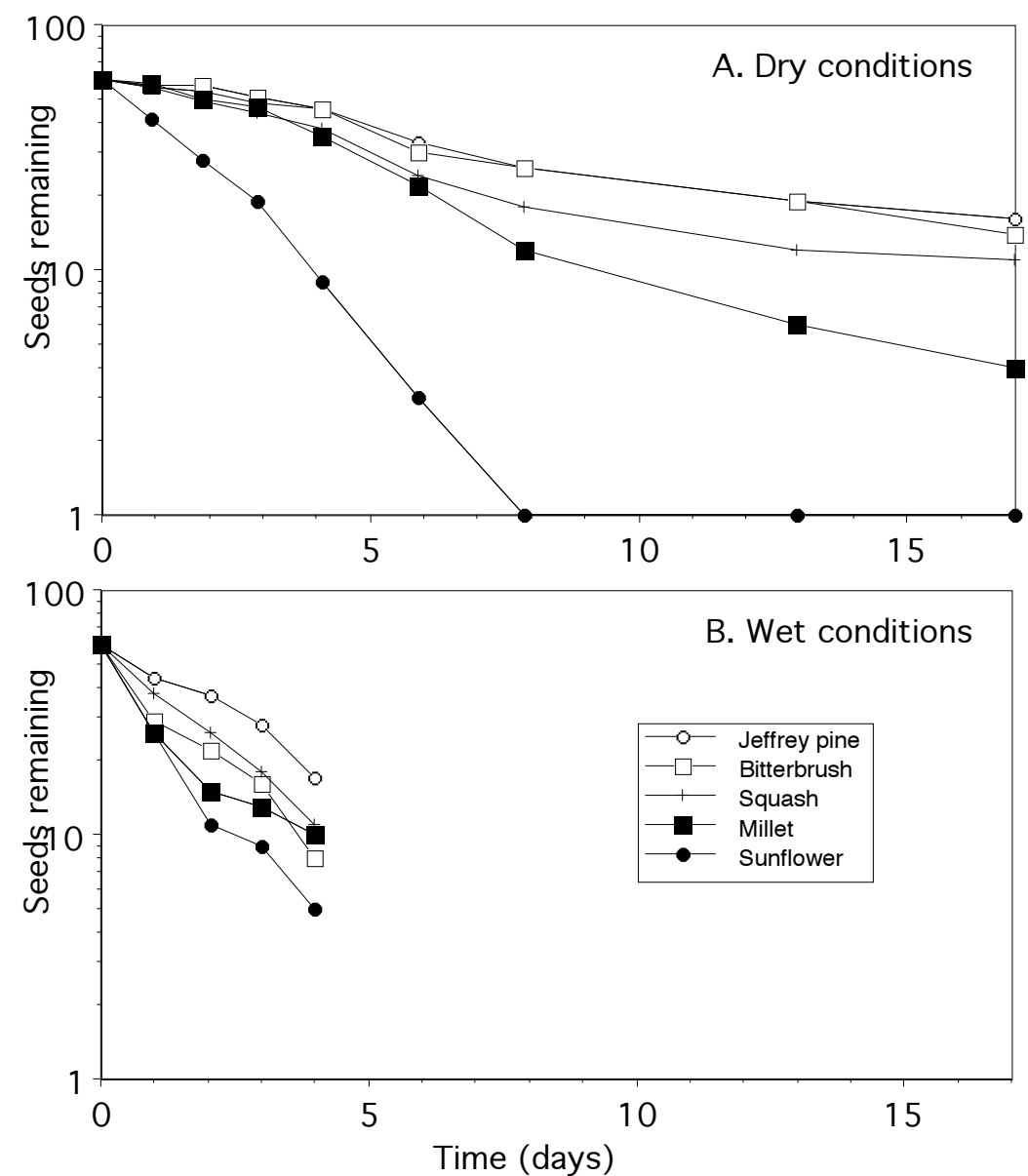

Fig. 1. Different rates of removal of 5 species of seeds from pine forest vegetation in Little Valley, Nevada, under dry (A) and wet (B) conditions. Dry trials were conducted during August 2003 and 2004 (data for the 2 years were combined because there was no significant year effect) and wet trials in October 2003.

dry conditions $\left(\chi^{2}=33.2, P<0.0001\right)$. Under dry conditions, sunflower was detected at a rate of $37.8 \%$ per day, followed by millet $(16.2 \%$ per day), acorn squash $(9.5 \%$ per day), bitterbrush (8.2\% per day), and Jeffrey pine (7.5\% per day). Wet conditions (Fig. 1B) resulted in a similar order of detectability; however, all species of seeds were removed much faster in wet conditions than under dry conditions: sunflower (46.8\% per day), bitterbrush $(39.5 \%$ per day), millet (36.1\% per day), acorn squash $(34.6 \%$ per day), and Jeffrey pine (27.0\% per day).

At Hot Springs Mountains, sunflower seeds disappeared faster than all other seed types (Fig. 2): 2.7 times faster than cheatgrass $\left(\chi^{2}=\right.$ 16.35, $P=0.0001), 2.4$ times faster than Indian ricegrass $\left(\chi^{2}=14.35, P=0.0002\right), 2.0$ times faster than millet seeds $\left(\chi^{2}=10.83, P=0.001\right)$, and 1.7 times faster than desert needlegrass seeds $\left(\chi^{2}=6.78, P=0.009\right)$. Desert needlegrass seeds were removed 1.6 times faster than cheatgrass seeds $\left(\chi^{2}=3.80, P=0.051\right)$. There were no other significant differences in removal rates among different seed types. There was a significant year effect; seeds disappeared slower in 2008 than in $2005\left(\chi^{2}=202.05, P<\right.$ $0.0001)$ and in $2006\left(\chi^{2}=337.82, P<0.0001\right)$.

At Red Rock, sunflower seeds disappeared faster than all other seed types (Fig. 3): sunflower seeds disappeared 5.3 times faster than millet $\left(\chi^{2}=11.93, P=0.0006\right), 2.9$ times faster than Ephedra $\left(\chi^{2}=8.41, P=0.0037\right)$, 2.8 times faster than bitterbrush seeds $\left(\chi^{2}=\right.$ 

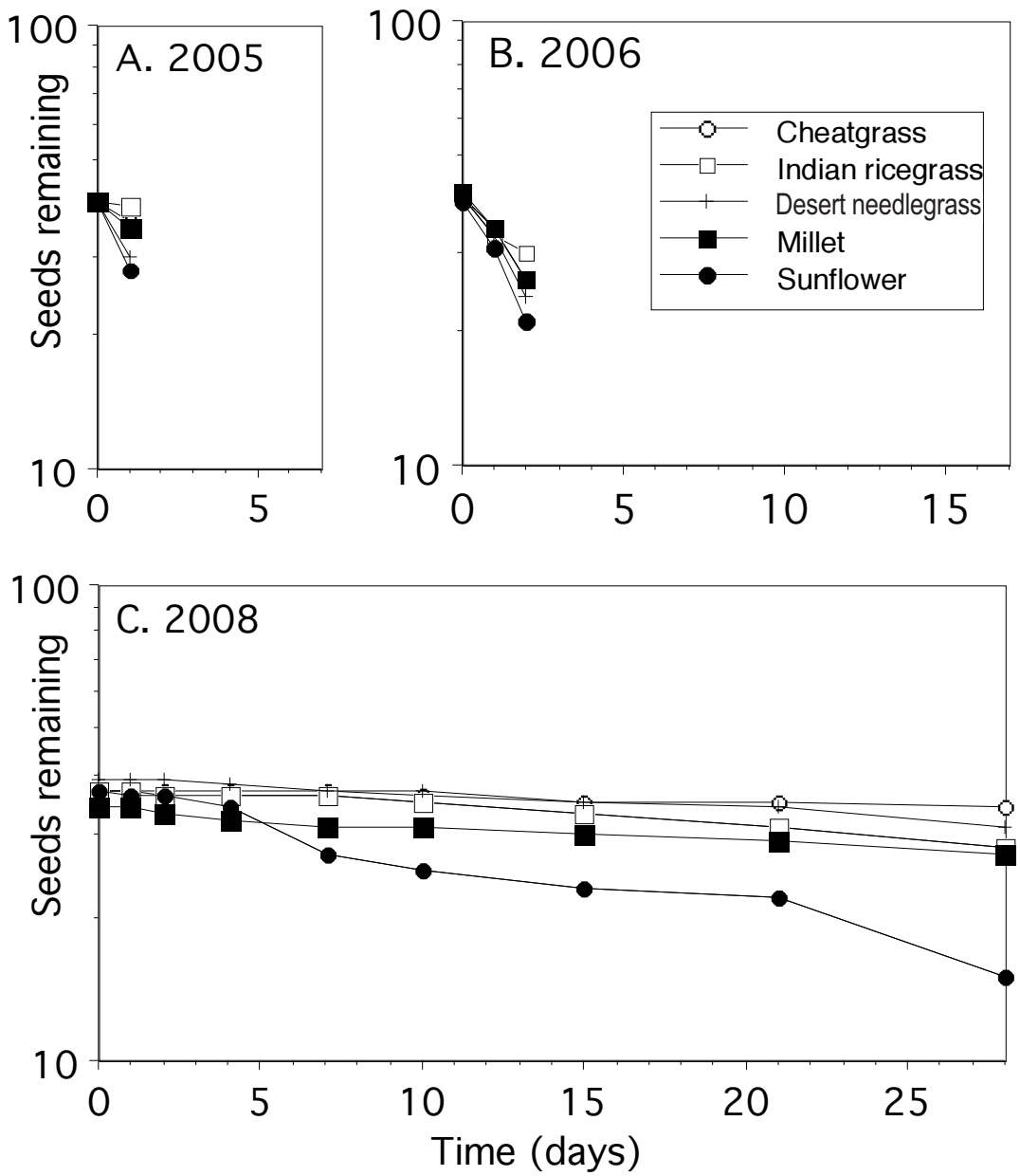

Fig. 2. Different rates of removal of 5 species of seeds from Great Basin Desert shrub (salt desert) vegetation in the Hot Springs Mountains, Nevada, under dry conditions during October 2005 (A), May 2006 (B), and June 2008 (C). The trials in 2005 and 2006 were interrupted by rain.

7.91, $P=0.0049$ ), and 1.9 times faster than cheatgrass seeds $\left(\chi^{2}=4.40, P=0.0358\right)$. Cheatgrass was removed 2.7 times faster than millet seeds $\left(\chi^{2}=4.29, P=0.0384\right)$. There were no other significant differences in removal rates among the different seed types. There was no significant year effect at this site.

\section{Discussion}

This study provided evidence that cultivated seeds were removed from caches faster than seeds from wildland plants at each of the 3 habitats. At all 3 habitats (i.e., rodent communities), cultivated sunflower seeds were removed from artificial caches faster than seeds from plants that were indigenous to the area. Sunflower seeds are large nutritious seeds that are high in lipids (Price 1983), and apparently emit a strong odor that rodents can readily detect. Taraborelli et al. (2009) found that 4 murid rodent species all detected and excavated buried sunflower seeds more frequently than other seed species. The other cultivated seed, millet, was more detectible to foraging rodents than the wildland seed types at the pine forest site but not at the 2 desert shrub sites. Millet seeds are lower in nutrients (Price 1983) and appear to have a weak odor to most humans (Hollander personal observation). In all of the cases except one, the wildland seed types were also native to the area. The exception 

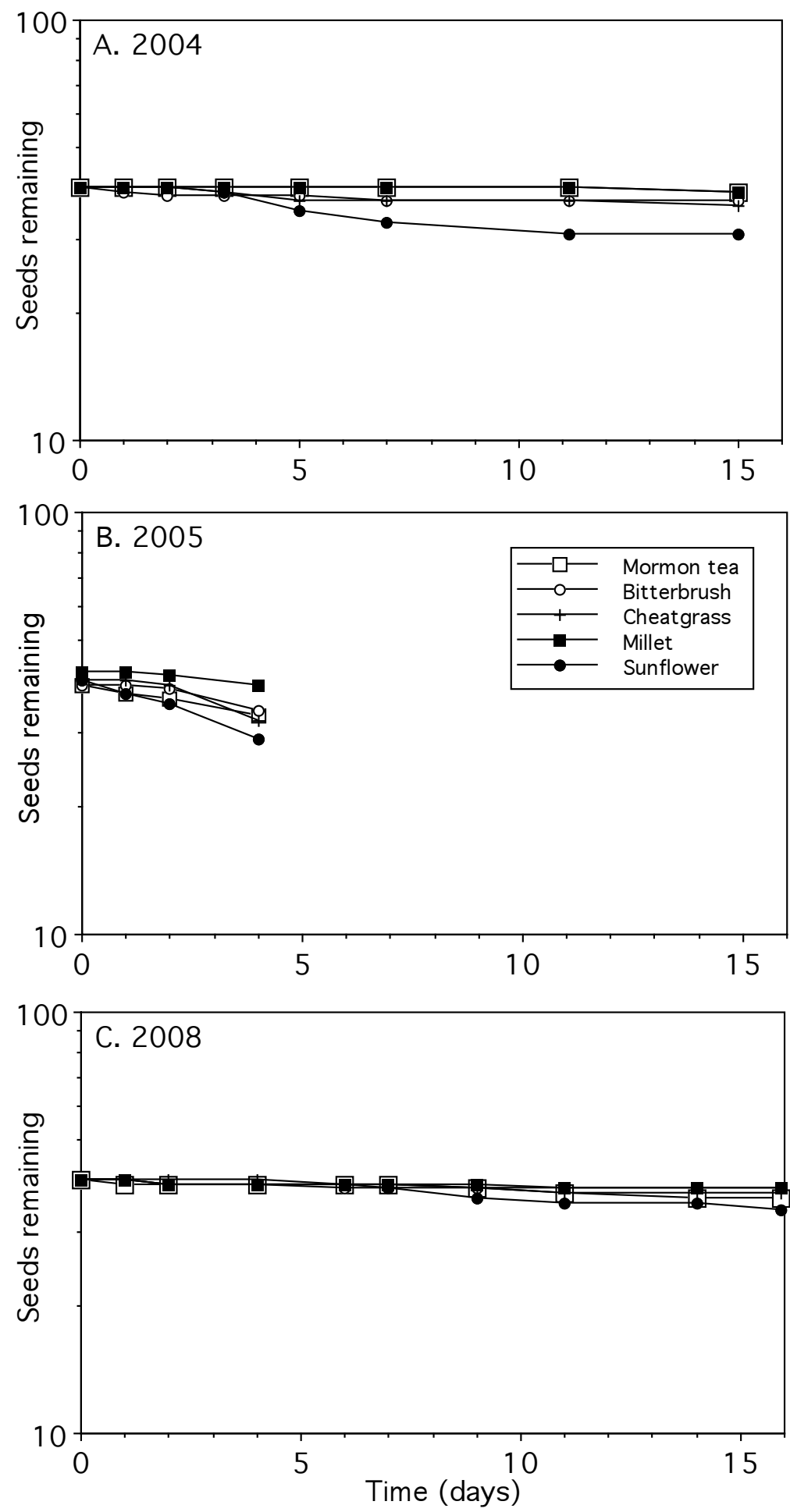

Fig. 3. Different rates of removal of 5 species of seeds from Great Basin Desert shrub (sagebrush) vegetation at Red Rock, Nevada, under dry conditions during September 2004 (A), September 2005 (B) and May 2008 (C). The trial in 2005 was interrupted by rain. 
was cheatgrass, which occurs at the 2 Great Basin Desert shrubland sites but was introduced from Eurasia (Mack 1981).

At Little Valley, where chipmunks are abundant, the pattern of removal was the most pronounced. Both Jeffrey pine and antelope bitterbrush seeds are important components of the diets of rodents at this site. Since we performed the main portion of our study during September and October, when pine seeds are harvested by animals, rodents were likely actively foraging for Jeffrey pine seeds throughout the duration of our study. Antelope bitterbrush seeds ripen in July, and portions of that seed crop were likely already stored in caches (Vander Wall 1994, Kuhn and Vander Wall 2008). In addition to the sunflower and millet seeds, the other cultivated seed type we used at Little Valley was acorn squash. Squash seeds were intermediate in the order of detection.

When we repeated trials under wet conditions, the order of detection was similar, with the only exception being bitterbrush seeds. Bitterbrush was fourth in the order of detectability under dry conditions but second under wet conditions. Several studies have shown that seeds in general are much more detectable under wet conditions, as they are hygroscopic and readily absorb water, which causes seeds to release odorant molecules (Vander Wall 1998, 2000, Jorgensen 2001). Bitterbrush seeds are more hygroscopic than the other seed types (Vander Wall 1993, 1998, Hollander personal observation), and this may explain the shift in the order of detection under wet conditions.

At Hot Springs Mountains, the pattern of seed removal was similar, although less pronounced. Sunflower and millet seeds were once again removed most rapidly. The significant year effect at this site was due to unexpected rainfall in 2005 and 2006, which caused us to terminate the study early in those years. During 2005, we collected the removal data after one day, it rained the following night, and we found almost all of the seeds had been removed by the next morning. In 2006, rainfall occurred on the third night. During 2008, we initiated and continued the trial under dry conditions for 28 days, and we observed a more revealing pattern. Indian ricegrass, the native seed that was removed at the slowest rate, is a preferred food source and is the most commonly cached seed species at this site (Longland et al. 2001).

At Red Rock, seed removal overall was extremely slow, and the pattern was not as consistent as it was at the other sites. This may have been because of low rodent abundance during the time of the study. Even though sunflower had a very slow removal rate at this site, it was still removed faster than all other seed types. Cheatgrass, an introduced grass that is typically abundant in sagebrush-dominated environments, such as the Red Rock site, was removed at the second fastest ratesignificantly faster than millet, which is a preferred food among several cultivated seed types (Price 1983).

We suggest that natural selection has acted on native seeds to reduce their olfactory signal, which could potentially reduce predation upon these seeds. Animals that scatter-hoard seeds retrieve seeds using spatial memory as well as olfaction. However, pilferers, which rely on olfaction and exploratory digging to find cached seeds, are likely to be thwarted by weak odors. Seeds that are less detectable to rodents using olfaction have a greater likelihood of remaining buried in the ground after being cached, even remaining less detectable to the original cacher. In the case of cheatgrass, detectability and, therefore, vulnerability to seed predation may be relatively high among wildland seeds due to a short history of interactions with granivores. Cheatgrass was only introduced in the mid-1800s to the North American deserts, which appear to harbor a uniquely high diversity and abundance of granivorous rodents among the world's desert environments (Kelt et al. 1996).

An alternative hypothesis is that rodents prefer to eat cultivated sunflower and, in some cases, millet seeds over the indigenous seeds that we tested. This might mean that all seeds are equally detectable but that rodents chose to ignore the less palatable native seeds. This seems unlikely because some of the native seeds that we tested are highly preferred foods, even when presented alongside sunflower seeds. At Little Valley, Jeffrey pine seeds are among the most highly preferred seeds that chipmunks and deer mice consume (Vander Wall 1995, Kuhn and Vander Wall 2009). During autumn, when pine seeds are abundant, it becomes more difficult to capture 
rodents by use of sunflower seed bait (S. Vander Wall personal observation). At the Hot Springs Mountains, Indian ricegrass is a highly preferred food for many species of heteromyid rodents (Longland et al. 2001). At Red Rock, bitterbrush seeds are a preferred food of deer mice and least chipmunks, but these seeds are often ignored by heteromyid rodents (personal observation). Similarly, Ephedra seeds (Hollander and Vander Wall, 2009) are not heavily utilized by heteromyids, but are sought after by other species of rodents. These data suggest that seed preference is not a valid explanation for the results that we obtained.

One implication of this study is that commercially available, cultivated seeds should not be used as surrogates for native seeds in experiments that involve olfaction and other forms of perceptual discrimination. Sunflower, millet, and perhaps other types of cultivated seeds have stronger odors and/or may be preferred overall and are likely to yield misleading results. Second, the relatively low odor of wildland seeds in this study should be looked for in native seeds in other communities, especially in arid and semiarid environments where dry conditions further suppress seed odors. Weak odors of wildland seeds suggest that these seeds have evolved ways of reducing the effectiveness of cache discovery of scatter-hoarding rodents. Being nutritionally attractive but having a weak odor may be a way in which certain wildland plants entice rodents to cache seeds, but it may reduce the chance that the seeds will be eventually retrieved, which should enhance their reproductive success (Vander Wall 2010).

Further research is required to clearly distinguish between seed preference and seed detection by rodents. Measuring emission of volatile compounds from these seed types under wet and dry conditions and conducting controlled animal studies may further elucidate this distinction.

\section{ACKNOWLEDGMENTS}

We thank Melany Aten, Jenny Briggs, David Hollander, Lindsay Dimitri, Christopher Moore, and Amanda Murray for their assistance in the field and with statistical analyses. We also thank Drs. Mary Price and Lee Drickamer for their helpful comments in the editing process.

\section{Literature Cited}

ALLISON, P.D. 1995. Survival analysis using the SAS system: a practical guide. SAS Institute, Inc., Cary, NC.

Hollander, J.L., AND S.B. Vander Wall. 2009. Dispersal syndromes of North American Ephedra. International Journal of Plant Sciences 170:323-330.

Hulme, P.E., AND C.W. Benkman. 2002. Granivory. Pages 132-154 in C. Herrera and O. Pellmyr, editors, Plant-animal interactions: an evolutionary approach. Blackwell Science, Padstow, Cornwall.

JACOBS, L.F. 1992. Memory for cache locations in Merriam's kangaroo rats. Animal Behavior 43:585-593.

JaCobs, L.F., and E.R. Liman. 1991. Grey squirrels remember the location of buried nuts. Animal Behavior 41:103-110.

Johnson, T.K., AND C.D. JoRGENSEN. 1981. Ability of desert rodents to find buried seeds. Journal of Range Management 34:312-314.

JORGENSEN, E.E. 2001. Emission of volatile compounds by seeds under different environmental conditions. American Midland Naturalist 145:419-422.

Kelt, D.A., J.H. Brown, E.J. Heske, P.A. Marquet, S.R. Morton, J.R.W. Reid, K.A. Roogovin, and G. ShenBRot. 1996. Community structure of desert small mammals: comparison across four continents. Ecology 77:746-761.

Kuhn, K.M., and S.B. Vander Wall. 2008. Linking summer foraging to winter survival in yellow-pine chipmunks (Tamias amoenus). Oecologia 157:349-360.

2009. Formation and contents of yellow-pine chipmunk (Tamias amoenus) winter larders. Western North American Naturalist 69:309-318.

LONGland, W.S., S.H. Jenkins, S.B. Vander WaLl, J.A. Veech, and S.S. Pyare. 2001. Seedling recruitment in Oryzopsis hymenoides: are desert granivores mutualists or predators? Ecology 82:3131-3148.

MACK, R.N. 1981. Invasion of Bromus tectorum L. into western North America: an ecological chronicle. Agro-Ecosystems 7:145-165.

Price, M.V. 1983. Laboratory studies of seed size and seed species selection by heteromyid rodents. Oecologia 60:259-263.

Taraborelli, P., N. Borruel, and A. Mangeaud. 2009. Ability of murid rodents to find buried seeds in the Monte Desert. Ethology 115:201-209.

Tiffney, B.H. 1984. Seed size, dispersal syndromes, and the rise of the angiosperms: evidence and hypothesis. Annals of the Missouri Botanical Garden 71:551-576.

VANDER WALL, S.B. 1991. Mechanisms of cache recovery by yellow pine chipmunks. Animal Behavior 41: 851-863.

1993. Seed water content and the vulnerability of buried seed to foraging rodents. American Midland Naturalist 129:272-281.

1994. Seed fate pathways of antelope bitterbrush: dispersal by seed-caching yellow pine chipmunks. Ecology 75:1911-1926.

1995. The effects of seed value on the caching behavior of yellow pine chipmunks. Oikos 74: 533-537.

1998. Foraging success of granivorous rodents: effects of variation in seed and soil water on olfaction. Ecology 79:233-241.

2000. The influence of environmental conditions on cache recovery and cache pilferage by yellow 
pine chipmunks (Tamias amoenus) and deer mice (Peromyscus maniculatus). Behavioral Ecology 11: 544-549.

2001. The evolutionary ecology of nut dispersal. Botanical Review 67:74-117.

2010. How plants manipulate the scatter-hoarding behaviour of seed-dispersing animals. Philosophical Transactions of The Royal Society B 365:989-997.
VANDER Wall, S.B., and S.H. JenKins. 2003. Reciprocal pilferage and the evolution of food-hoarding behavior. Behavioral Ecology 14:656-667.

Received 12 August 2011 Accepted 26 April 2012 